\title{
Leptin Receptor Immunoreactivity in Chemically Defined Target Neurons of the Hypothalamus
}

\author{
Marie-Louise Håkansson, ${ }^{1}$ Hilary Brown, ${ }^{1}$ Nico Ghilardi, ${ }^{2}$ Radek C. Skoda, ${ }^{2}$ and Björn Meister ${ }^{1}$ \\ ${ }^{1}$ Department of Neuroscience, Karolinska Institute, S-171 77 Stockholm, Sweden, and 'Department of Pharmacology, \\ Biozentrum, University of Basel, 4056 Basel, Switzerland
}

\begin{abstract}
The adipose tissue-derived hormone leptin regulates body weight homeostasis by decreasing food intake and increasing energy expenditure. The weight-reducing action of leptin is thought to be mediated primarily by signal transduction through the leptin receptor (LR) in the hypothalamus. We have used immunohistochemistry to localize LR-immunoreactive (LR-IR) cells in the rat brain using an antiserum against a portion of the intracellular domain of LR that is common to all LR isoforms. The antiserum recognized the short and long isoforms of LR in transfected hematopoietic BaF3 cells. To examine the chemical nature of target cells for leptin, direct double-labeling immunofluorescence histochemistry was applied. The results show extensive distribution of LR-like immunoreactivity (LR-LI) in the brain with positively stained cells present, e.g., in the choroid plexus, cerebral cortex, hippocampus, thalamus, and hypothalamus. In the hypothalamus, strongly LR-IR neurons were present in the supraoptic nucleus (SON) and paraventricular nucleus (PVN), periventricular nucleus, arcuate nucleus, and lateral hypothalamus. Weaker LR-IR neurons were also demonstrated in the lateral and medial preoptic nuclei, suprachiasmatic nucleus, ventromedial and dorsomedial nuclei, and tuberomammillary nucleus. Confocal laser scanning microscopy
\end{abstract}

showed LR-LI in the periphery of individual cells. In magnocellular neurons of the SON and PVN, LR-LI was demonstrated in vasopressin- and oxytocin-containing neurons. In parvocellular neurons of the PVN, LR-LI was demonstrated in many corticotropin-releasing hormone-containing neurons. LR-IR neurons were mainly seen in the ventromedial aspect of the arcuate nucleus, where LR-LI co-localized with neuropeptide Y. In the ventrolateral part of the arcuate nucleus, LR-LI was present in many large adrenocorticotropic hormone-IR proopiomelanocortin-containing neurons and in a few galanin-, neurotensin-, and growth hormone-releasing hormonecontaining neurons. In the dorsomedial arcuate nucleus, few tyrosine hydroxylase (dopamine)-containing neurons were seen to have LR-LI. Melanin-concentrating hormone-containing neurons in the lateral hypothalamus had LR-LI. Based on the immunohistochemical results, possible interactions of leptin with brain mechanisms are discussed.

Key words: arcuate nucleus; $\mathrm{CRH}$; dopamine; galanin; $\mathrm{GHRH;} \mathrm{immunohistochemistry;} \mathrm{lateral} \mathrm{hypothalamic} \mathrm{area;}$ LHRH; MCH; neurotensin; NPY; oxytocin; paraventricular nucleus; POMC; somatostatin; supraoptic nucleus; vasopressin
The recently cloned obese $(o b)$ gene encodes a circulating signaling factor called leptin produced by adipocytes that regulates body weight homeostasis (Zhang et al., 1994b). The crystal structure of leptin has revealed a four-helix bundle similar to that of the long-chain helical cytokine family (Zhang et al., 1997). Homozygous $o b / o b$ mice that have a mutation in the $o b$ gene exhibit obesity, diabetes, and infertility. Exogenous administration of recombinant leptin corrects the defects in $o b / o b$ mice and induces weight reduction in mice with diet-induced obesity as well as in normal mice by decreasing food intake and increasing energy expenditure (Campfield et al., 1995; Halaas et al., 1995; Pelleymounter et al., 1995; Stephens et al., 1995). Injection of leptin directly into the third ventricle reduces body weight at low doses (Campfield et al., 1995), suggesting that leptin acts primarily via the CNS.

Mutations in the mouse diabetes $(\mathrm{db})$ gene results in a phenotype indistinguishable from $o b / o b$ mice (Hummel et al., 1966).

Received June 6, 1997; revised Oct. 27, 1997; accepted Nov. 3, 1997.

This research was supported by Swedish Medical Research Council Grant 04X10358, grants from Stiftelsen Tornspiran, Åhlén-Stiftelsen, Magnus Bergvalls Stiftelse, Ake Wibergs Stiftelse, Stiftelsen Sigurd, and Elsa Goljes Minne, and funds from the Karolinska Institute.

Correspondence should be addressed to Dr. Björn Meister, Department of Neuroscience, Karolinska Institute, S-171 77 Stockholm, Sweden.

Copyright (C) 1997 Society for Neuroscience $0270-6474 / 97 / 180559-14 \$ 05.00 / 0$
Results from parabiosis studies using $o b / o b$ and $d b / d b$ mice (Coleman, 1973), together with the demonstration of failure of $d b / d b$ mice to respond to injection of leptin and the high levels of leptin in adipose tissue combined with high serum levels of leptin in $d b / d b$ mice (Campfield et al., 1995; Halaas et al., 1995), indicate that $d b / d b$ mice may be defective in reception of the $o b$ gene product signal. Recently, the gene for mouse leptin receptors (LR) was cloned and shown to be mutated in $d b / d b$ mice (Tartaglia et al., 1995; Chen et al., 1996; Lee et al., 1996). LR is a single transmembrane-spanning receptor and a member of the cytokine receptor superfamily that includes the gp130 signaltransducing component of the receptors for interleukin-6, granulocyte colony-stimulating factor, and leukemia-inhibitory factor (Tartaglia et al., 1995). Four different LR (originally designated Ob-Ra-d) variants arise from the $d b$ gene via alternate splicing (Lee et al., 1996). A fifth isoform represents a soluble form of the receptor (Lee et al., 1996). One of the splice variants (LR isoform b), which has a long cytoplasmic domain of 302 amino acids, is expressed primarily in the hypothalamus and is spliced abnormally in C57BL/Ks $d b / d b$ mice (Chen et al., 1996; Ghilardi et al., 1996; Lee et al., 1996). The C57BL/Ks $d b / d b$ mutation generates a new splice donor that interferes with the correct splicing of LR isoform b mRNA and is predicted to cause absence of the LR isoform b protein in $d b / d b$ mice (Lee et al., 1996). The intracel- 

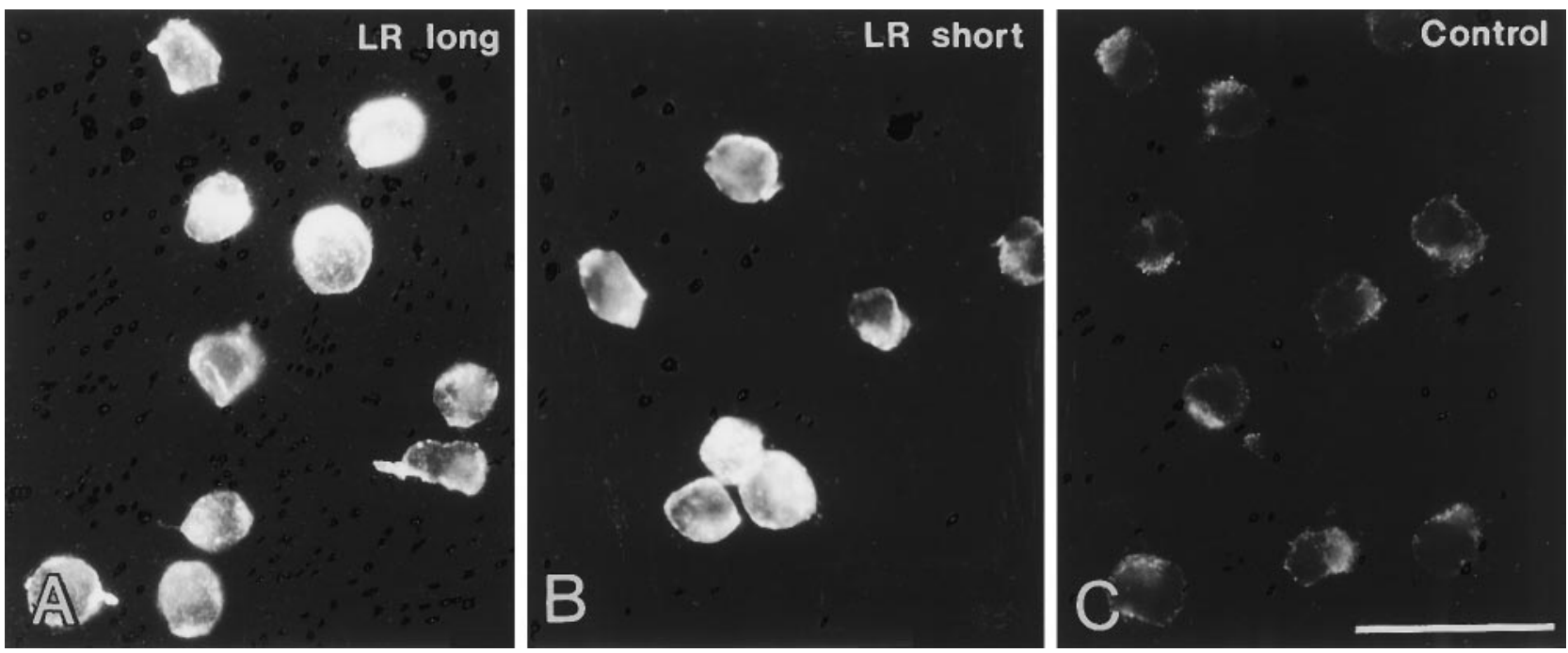

Figure 1. Immunofluorescence photomicrographs of hematopoietic BaF3 cells transfected with short $(A)$ or long $(B) \mathrm{LR}$ isoforms or control BaF3 cells $(C)$. There is strong LR-LI in transfected cells $(A, B)$ but absence of LR-LI in control cells $(C)$. Weak fluorescence in control cells is represented by autofluorescence $(C)$. Scale bar, $50 \mu \mathrm{m}$.

lular domain of short LR isoform a, which is present in $d b / d b$ mice, contains the box 1 motif but lacks the box 2 motif, required for activation of cytoplasmic tyrosine kinases of the janus kinase (JAK) family (Chen et al., 1996; Lee et al., 1996). JAKs phosphorylate cytoplasmic target proteins such as signal transducers and activators of transcription (STAT). Phosphorylation of STAT proteins induces dimerization and translocation into the nucleus and results in specific activation of gene transcription (Ihle, 1996). The short form of LR present in $d b / d b$ mice is therefore unable to activate the JAK-STAT pathway (Baumann et al., 1996; Ghilardi et al., 1996; Ghilardi and Skoda, 1997).

The weight-reducing effects of leptin are likely to be mediated by JAK-STAT signal transduction via LR in the hypothalamus. Specific ${ }^{125}$ I-leptin binding sites have been demonstrated in the hypothalamic arcuate nucleus-median eminence complex and in the choroid plexus (Banks et al., 1996). LR mRNA is present in several hypothalamic nuclei, including the arcuate, paraventricular, supraoptic, ventromedial, and dorsomedial nuclei and lateral hypothalamic area, as revealed by in situ hybridization (Håkansson et al., 1996; Huang et al., 1996; Mercer et al., 1996a,b; Fei et al., 1997). Because chemical lesioning of the hypothalamic arcuate nucleus results in severe obesity (see Meister, 1991), this nucleus has been assumed to play a major role for the action of leptin on the CNS. Within the arcuate nucleus, LR mRNAexpressing neurons are primarily present in the ventromedial part, and they have been shown to contain neuropeptide Y (NPY) mRNA (Håkansson et al., 1996; Huang et al., 1996; Schwartz et al., 1996a; Mercer et al., 1996a,b).

So far, the precise cellular localization of LR at the protein level has not been reported, and the chemical identities of neurons expressing LR protein have only been defined to a very limited extent. The neurotransmitters and neuropeptides that mediate the actions of leptin are not known. Knowledge of the cellular localization of LR and the chemical content of LRcontaining neurons is essential for the understanding of the mechanism by which circulating leptin induces weight reduction via the CNS. In the present study we have used immunohistochemistry to elucidate the cellular localization of LR-like immunoreactivity (LR-LI) in the rat hypothalamus and to identify the chemical nature of LR-immunoreactive (LR-IR) hypothalamic neurons with emphasis on chemical messengers that have been implicated previously in the regulation of ingestive behavior.

\section{MATERIALS AND METHODS}

Male Sprague Dawley rats (150-200 g body weight; B \& K Universal, Stockholm, Sweden) were anesthetized with sodium pentobarbital (Mebumal; $40 \mathrm{mg} / \mathrm{kg}$, i.p.) and perfused via the ascending aorta with $50 \mathrm{ml}$ of $\mathrm{Ca}^{2+}$-free Tyrode's solution $\left(37^{\circ} \mathrm{C}\right)$ followed by $50 \mathrm{ml}$ of formalinpicric acid fixative $\left(37^{\circ} \mathrm{C}\right)(4 \%$ paraformaldehyde and $0.4 \%$ picric acid in $0.16 \mathrm{M}$ phosphate buffer, $\mathrm{pH}$ 6.9). Perfusions were continued thereafter for $6 \mathrm{~min}$ with ice-cold fixative as above. Some rats received an injection of colchicine $(120 \mu \mathrm{g}$ in $20 \mu \mathrm{l}$ of $0.9 \% \mathrm{NaCl}$; Sigma, St. Louis, MO) into the lateral ventricle $24 \mathrm{hr}$ before sacrifice. Colchicine is known to arrest axonal transport, thereby increasing levels of transmitters, enzymes, and peptides and proteins in the cell soma.

Tissues were dissected out rapidly, post-fixed in the same fixative for 90

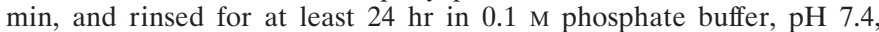
containing $10 \%$ sucrose, $0.02 \%$ Bacitracin (Sigma), and $0.01 \%$ sodium azide (Merck, Darmstadt, Germany) in $0.1 \mathrm{~m}$ phosphate buffer, pH 7.4. Sections were cut $(14 \mu \mathrm{m})$ in a cryostat and incubated at $4^{\circ} \mathrm{C}$ overnight with goat polyclonal antiserum to LR (antiserum sc-1834, lot G116, diluted 1:1000; Santa Cruz Biotechnology, Santa Cruz, CA). Antiserum sc-1834 has been raised to an epitope corresponding to amino acids 877-894 (KNCSWAQGLNFQKRTDTL) mapping at the C terminus of the short form of mouse LR. The mouse immunogen peptide sequence shows $94 \%$ homology with the rat sequence (one amino acid mismatch).

BaF3 cells stably transfected with LR expression constructs were grown as described previously (Ghilardi and Skoda, 1997), fixed in 4\% paraformaldehyde and $0.4 \%$ picric acid in $0.16 \mathrm{M}$ phosphate buffer, $\mathrm{pH}$ 6.9, and incubated with primary antiserum to LR. Sections were also double-labeled by combining goat antiserum to LR (diluted 1:500 for double-labeled sections) with mouse monoclonal antibodies to adrenocorticotropic hormone (ACTH; 1:1,000; Peninsula Laboratories, Belmont, CA) or rabbit antiserum to oxytocin (OT; 1:1600; Peninsula Laboratories), corticotropin-releasing hormone (CRH; 1:1600; a kind gift from Dr. W. Vale, The Salk Institute, La Jolla, CA), galanin (GAL; 1:800; Peninsula Laboratories), growth hormone-releasing hormone (GHRH; 1:4000; a kind gift from Dr. W. Vale), luteinizing hormone-releasing hormone (LHRH; 1:1000; IncStar, Stillwater, $\mathrm{MN})$, melanin-concentrating hormone (MCH; 1:800; a kind gift from Dr. W. Vale), NPY (1:400; Peninsula Laboratories), neurotensin (NT; 1:800; a kind gift from Dr. P. Frey, Sandoz Research Institute, Bern, Switzerland), somatostatin (SOM; 1:800; a kind gift from Dr. R. Elde, University of Minnesota, Minneapolis, MN), tyrosine hydroxylase (TH; 1:800; a kind gift from Dr. M. Goldstein, New York University 

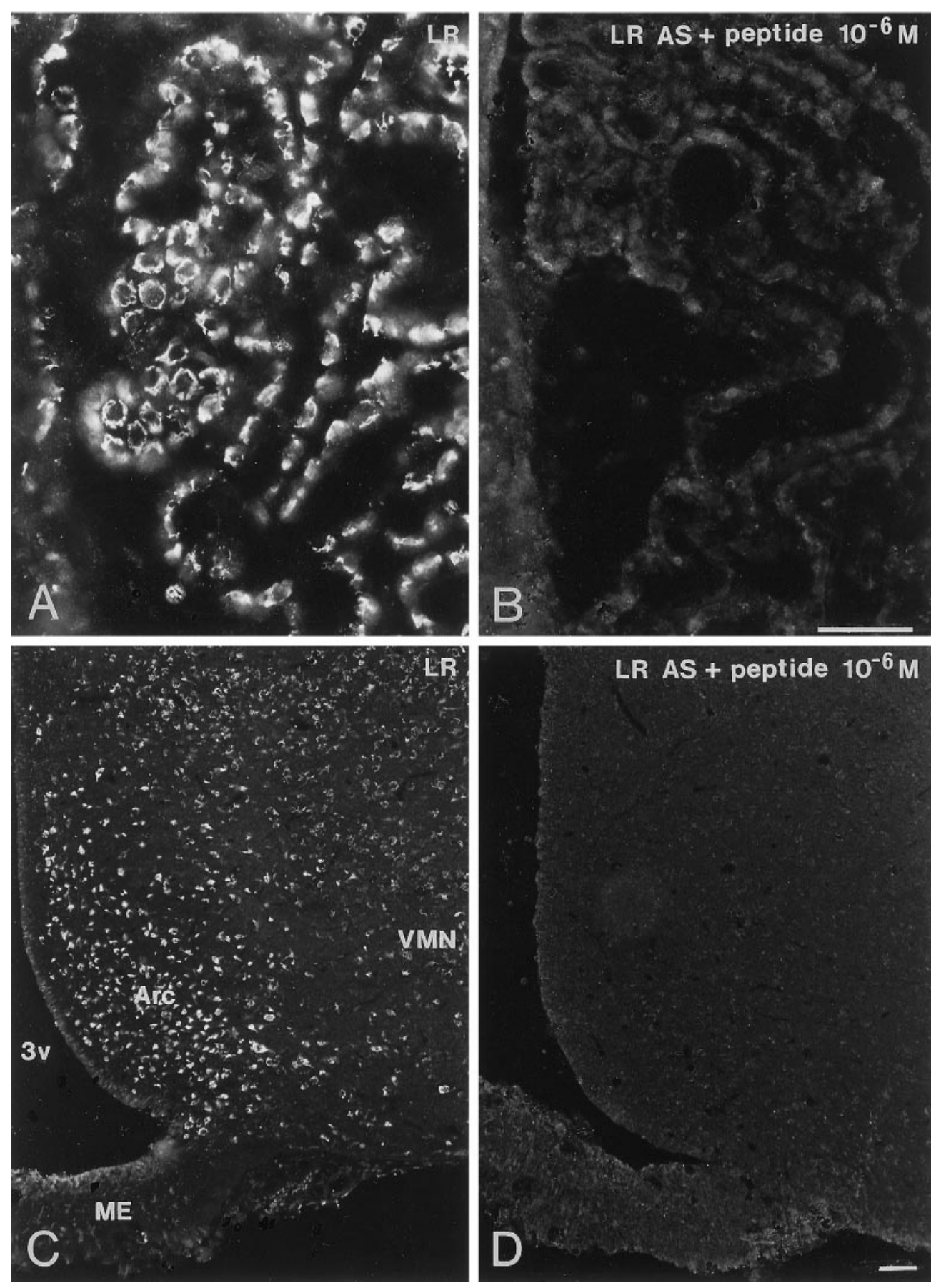

Figure 2. Immunofluorescence photomicrographs of sections of the choroid plexus $(A, B)$ and hypothalamic arcuate nucleus $(C, D)$ after incubation with antiserum to LR $(A, C)$ or antiserum to LR preadsorbed with immunogen peptide $\left(10^{-6} \mathrm{M}\right)(B, D)$. Strong LR-LI is present in the periphery of cells in the choroid plexus $(A)$. In the arcuate nucleus (Arc), strong LR-LI is seen mainly in the ventromedial part of the nucleus but also in some neurons belonging to the dorsomedial and ventromedial part. Weaker LR-LI is present in the ventromedial nucleus $(V M N)$. Note total absence of LR-LI in sections incubated with preadsorbed antiserum. ME, Median eminence; $3 v$, third ventricle. Scale bars, $50 \mu \mathrm{m}$.
Medical Center, New York, NY), or vasopressin (VP; 1:6000; a kind gift from Dr. A. Burlet, Institut National de la Santé et de la Recherche Médicale). Some sections were incubated with antiserum to LR that had been preadsorbed with the immunogen peptide (Santa Cruz Biotechnology) at $10^{-6} \mathrm{M}$. After rinsing in PBS, the sections were incubated for $30 \mathrm{~min}$ at $37^{\circ} \mathrm{C}$ with $\mathrm{Cy} 3$-conjugated donkey anti-goat secondary antibodies (final dilution, 1:250; Jackson ImmunoResearch, West Grove, PA).

For the double-stained sections, lissamine-rhodamine-conjugated donkey anti-goat (1:80; Jackson ImmunoResearch) and fluorescein isothiocyanate (FITC)-conjugated donkey anti-rabbit or donkey anti-mouse antibodies (1:80; Jackson ImmunoResearch) were used. After rinsing in PBS, the sections and culture slides were mounted in a mixture or PBS and glycerol (1:3) containing $0.1 \%$ p-phenylenediamine.

The sections and cells were examined with a Nikon Microphot-SA epifluorescence microscope. Specimens were also examined with a Bio-
Rad (Cambridge, MA) MRC-600 confocal imaging system. As excitation source a krypton-argon ion laser (model 5470K; Ion Laser Technology, Salt Lake City, UT) with output at 488, 568, and $647 \mathrm{~nm}$ was used. FITC was imaged with $488 \mathrm{~nm}$ excitation and a $505-540 \mathrm{~nm}$ bandpass emission filter. Lissamine-rhodamine B- and Cy3-labeled tissue was imaged with $568 \mathrm{~nm}$ excitation and a 598-621 nm bandpass emission filter. The images shown are the results of one optical section. The images were printed using a Tektronix Phaser IIsd printer.

\section{RESULTS}

To asses the specificity of the LR antibodies, we performed immunofluorescence on transfected cell lines expressing LR and nontransfected control cells. Incubation of a mouse hematopoietic cell line, BaF3, transfected with the long or short LR variants 

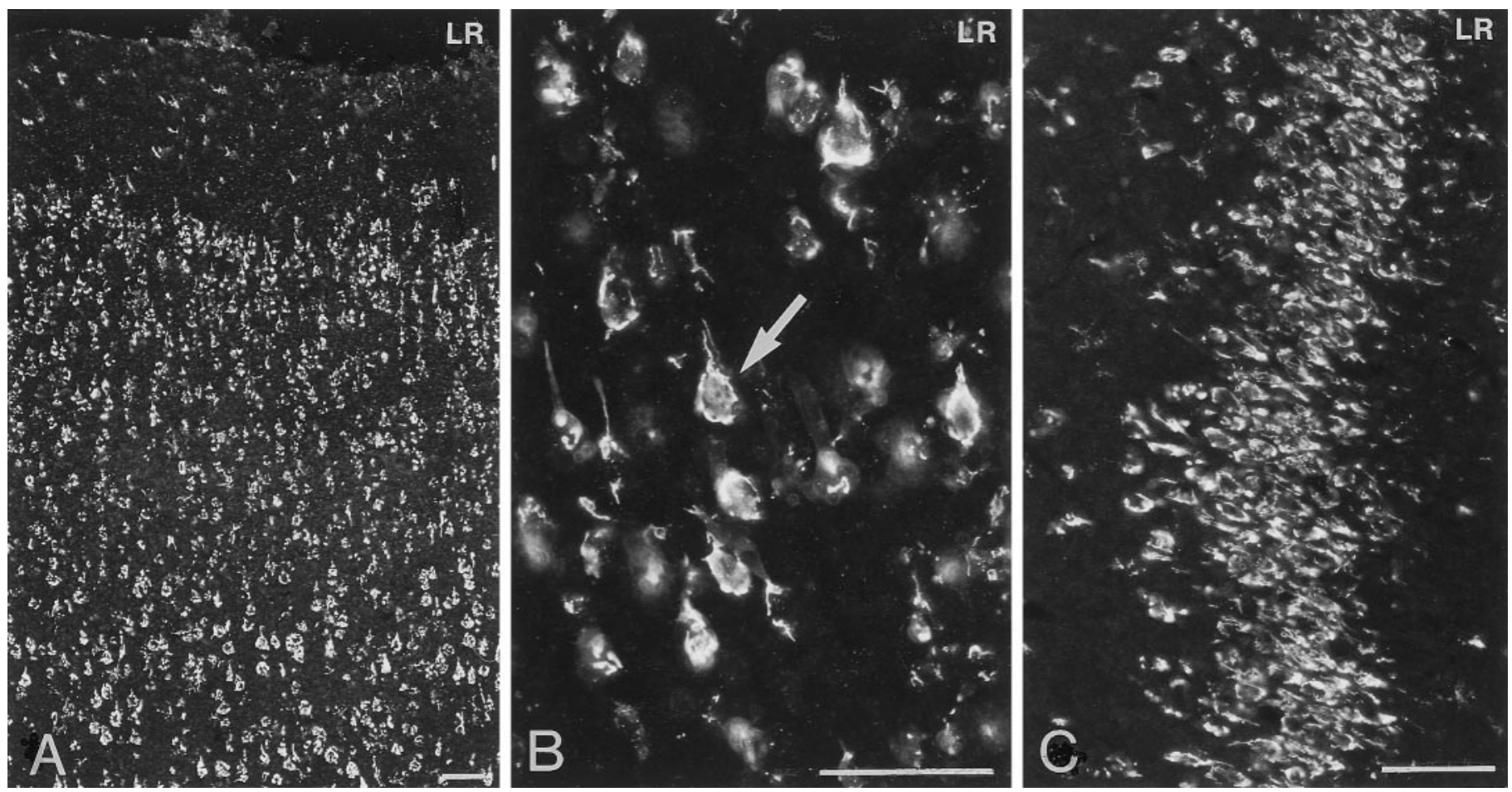

Figure 3. Immunofluorescence photomicrographs of sections of the rat cerebral cortex $(A, B)$ and the CA3 region of the hippocampus $(C)$ after incubation with antiserum to LR. Strong LR-LI is present in neurons in layers II-VI of the cerebral cortex $(A)$ and in neurons of the CA3 region of the hippocampus. At higher magnification $(B)$, it can be seen that LR-LI is present in the periphery of pyramidal neurons (see arrow in $B$ ). Scale bars, $50 \mu \mathrm{m}$.

with antiserum to LR resulted in strong staining (Fig. $1 A, B$ ), whereas the nontransfected control BaF3 cells were devoid of LR-LI (Fig. 1C). However, the nontransfected control BaF3 cells showed very weak autofluorescence (Fig. $1 C$ ).

LR-IR neurons were distributed widely in the rat brain. Incubation of sections from rat brain, including interalia choroid plexus, cerebral cortex, thalamus, and hypothalamus, with LR antiserum preabsorbed with control peptide, corresponding to amino acids 877-894 mapping at the $\mathrm{C}$ terminus of LR of mouse origin, abolished all immunoreactivity (Fig. 2A-D). Strongly LR-IR neurons were demonstrated in the layers II-VI of the cerebral cortex (Fig. $3 A$ ). Within individual pyramidal neurons, LR-LI was located in the periphery of the cell (Fig. $3 B$ ). LR-IR neurons were distributed in CA1-3 and the dentate gyrus of the hippocampus (Fig. 3C). Many LR-IR neurons were also distributed in the thalamus and brainstem nuclei (data not shown). Many nuclei of the hypothalamus contained LR-IR neurons. In the rostral forebrain and in the preoptic area, moderately strong LR-LI was demonstrated in neurons of the medial preoptic area, lateral preoptic area, and the organum vasculosum of lamina terminalis. In the anterior hypothalamus, the periventricular nucleus contained moderately strong LR-IR neurons (Fig. 4A). Weak LR-LI was seen in many cells of the suprachiasmatic nucleus (Fig. $4 A$ ). Most magnocellular neurons of the SON (Figs. $4 A, B, 5,6 A$ ) and the PVN (Figs. $4 A, 6 C$ ) as well as accessory magnocellular neurons (Fig. $4 A$ ) were all strongly LR-IR. Within individual neurons of the SON, LR-LI was confined to the periphery of the neurons, as revealed by confocal scanning laser microscopy (Fig. 5). Parvocellular neurons of the PVN had strong LR-LI (Figs. 4A, 7A). At midhypothalamic levels, strongly LR-IR neurons could be seen in the caudal extension of the SON (Fig. $4 B$ ). Strong LR-LI was present in neurons of the arcuate nucleus, in particular in small neurons of the ventromedial aspect of the nucleus, but also in some larger neurons in the ventrolateral part (Figs. $4 B, 8 A, C, 9 A, C, 10 A, C, 11 C, E$ ). Weak LR-LI was seen in many neurons of the ventromedial and dorsomedial nuclei (Figs. $4 B, 8 A, 9 A, 11 C)$. The lateral hypothalamus contained many large neurons with strong LR-LI (Figs. $4 B, 12 A, C$ ). At posterior hypothalamic levels, strongly LR-IR neurons were again seen in the arcuate nucleus and lateral hypothalamus, whereas the tuberomammillary nucleus had only weakly LR-IR neurons (data not shown).

Direct double-labeling showed that LR-LI was present in many OT-containing (Fig. 6, compare $A$ with $B$ ) and VP-containing (compare Fig. 6, compare $C$ with $D$ ) magnocellular neurons of the SON and PVN. Few, if any, LHRH-containing neurons showed LR-LI (data not shown). Parvocellular neurons of the PVN that were LR-IR also contained CRH-LI (Fig. 7, compare $A$ with $B$ ). LR-IR and NPY-containing neurons were both located in the ventromedial aspect of the arcuate nucleus (Fig. 8, compare $A$ with $B)$. At higher magnification, it was seen that LR-LI was present in many NPY neurons (Fig. 8, compare $C$ with $D$ ). In the ventrolateral part of the arcuate nucleus, many large LR-IR neurons were demonstrated to contain ACTH-LI (Fig. 9, compare $A, C$ with $B, D)$. Few small neurons in the dorsomedial part of the arcuate nucleus contained LR-LI, and some of these were TH-positive (Fig. 10, compare $A$ with $B$ ). Few parvocellular neurons in the ventrolateral part of the arcuate nucleus showed LR-LI, and in some instances these were found to be GAL-IR (Fig. 10, compare $C$ with $D$ ), NT-IR (data not shown), and GHRH-IR (Fig. 11, compare $C, E$ with $D, F$ ). LR-positive, GHRH-negative cells, however, were also encountered (Fig. 11, compare $E$ with $F$ ). Some LR-IR cells in the anterior periventricular nucleus were also SOM-IR (Fig. 11, compare $A$ with $B$ ). 

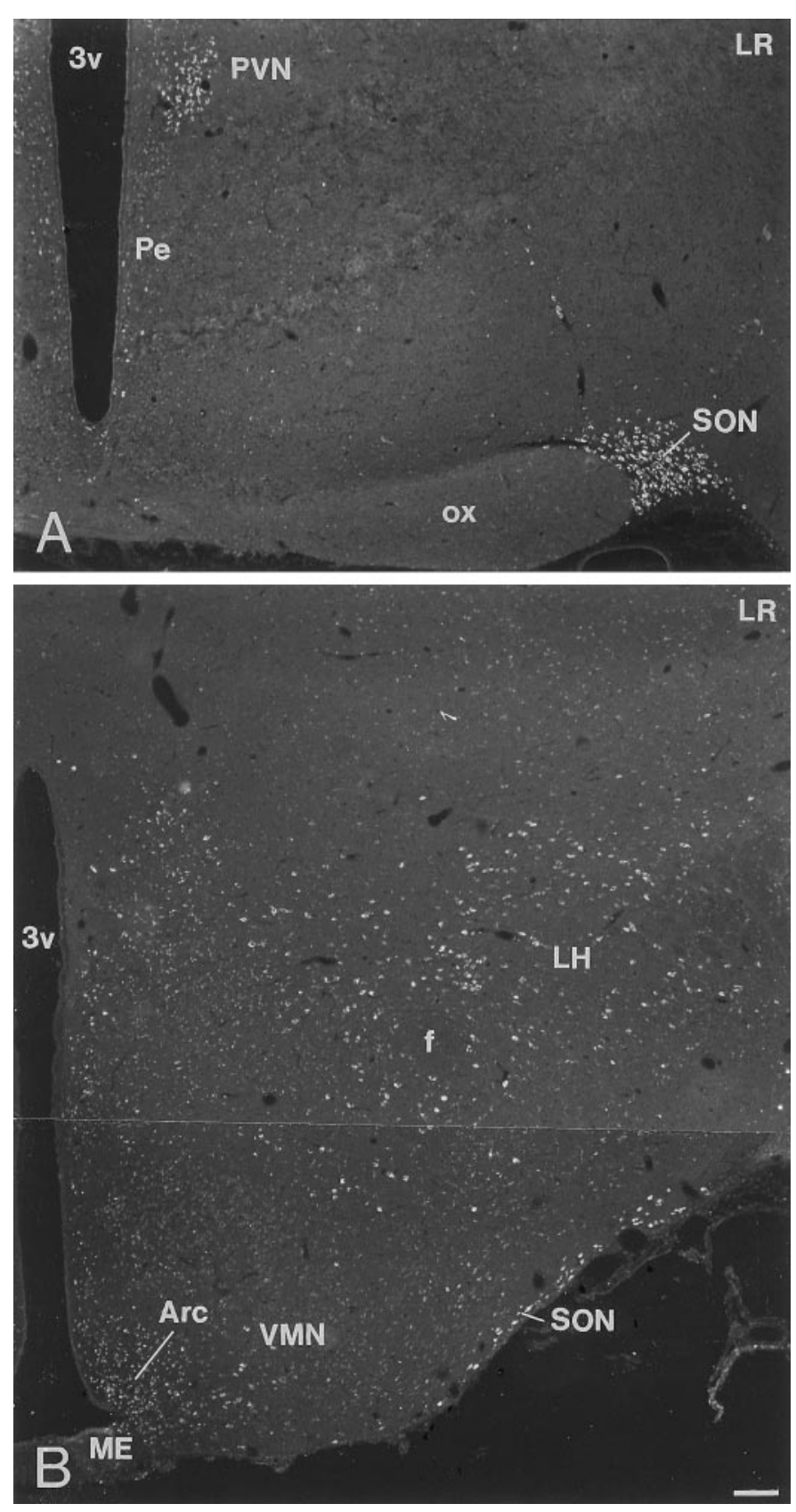

Figure 4. Immunofluorescence photomicrographs of sections from two different levels of the rat hypothalamus after incubation with antiserum to LR. In the anterior hypothalamus, strong LR-LI is present in the magnocellular supraoptic nucleus $(S O N)$ and paraventricular nucleus $(P V N)$. Weaker LR-IR cells are also encountered in the parvocellular PVN and in the periventricular nucleus $(P e)$. At a midhypothalamic level, strong LR-LI is present in the arcuate nucleus $(A r c)$, the caudal extension of the SON, and the lateral hypothalamus $(L H)$. Weaker LR-LI is seen in the ventromedial nucleus $(V M N) . f$, Fornix; $M E$, median eminence; $3 v$, third ventricle. Scale bar, $100 \mu \mathrm{m}$.

In the lateral hypothalamus, strongly LR-IR cells also contained MCH-LI (Fig. 12, compare $A, C$ with $B, D$ ), however, LR-IR cells that did not contain MCH-LI also could be seen (Fig. 12, compare $C$ with $D)$.

\section{DISCUSSION}

Our results show presence of LR-LI in neurons of the hypothalamus as well as in other brain regions such as the cerebral cortex, hippocampus, thalamus, and brainstem and in cells of the choroid plexus. This distribution pattern is in agreement with the recently described distribution of LR mRNA, as shown by in situ hybridization (Håkansson et al., 1996; Huang et al., 1996; Mercer et al., 1996a). In the hypothalamic arcuate nucleus, LR-LI was mainly present in the ventromedial part, where ${ }^{125}$ I-leptin binding sites also have been demonstrated (Banks et al., 1996). The specificity of the antiserum used in our study was verified by complete elimination of LR-LI after preadsorption of the antiserum with the immunogen peptide. Furthermore, we detected positive staining of BaF3 cells stably transfected with either short or long LR variants and absence of staining in the control BaF3 cells. Confocal laser scanning microscopy revealed LR-LI in the cell periphery, in agreement with the fact that the antiserum was raised against a part of the intracellular domain of LR.

Because the antiserum is generated against a peptide that is common to all isoforms, including the long form of the receptor ( $\mathrm{LR}$ isoform b), it is expected to recognize LR isoforms a-d. Thus, the antiserum should not discriminate between different LR isoforms, which also was supported by the fact that the antiserum recognized both long and short variants in transfected BaF3 cells. Using in situ hybridization with probes common to the short intracellular domain and with probes specific for the long splice variant, hybridization has been observed in the hypothalamus (Håkansson et al., 1996; Mercer et al., 1996a; Fei et al., 1997). However, probes to the long LR give only minimal labeling in choroid plexus (Håkansson et al., 1996; Mercer et al., 1996a). Reverse transcription-PCR analysis also has shown that the long LR is detected primarily in the hypothalamus (Lee et al., 1996). Taken together, these results suggest that the short form of the LR (mainly LR isoform a) is expressed in the choroid plexus, whereas the long LR form dominates in the hypothalamus. However, it remains to be shown that the extensive distribution of LR in the hypothalamus represents the active full-length receptor variant. Therefore, it will be interesting to use antisera specific for the long LR in future immunohistochemical experiments.

Evidence supports the fact that the long LR isoform is the principal mediator of the effect of leptin. The short LR isoform was inactive in generating a proliferative signal and JAK activation in BaF3 cells, a factor-dependent hematopoietic cell line, whereas the long isoform was able to generate both a proliferative signal and to activate JAK2 (Ghilardi and Skoda, 1997). Furthermore, despite the presence of short LR isoforms, $d b / d b$ mice are resistant to leptin. The role of short LR isoforms is unclear at present. Alternative splice variants resulting in proteins with truncated cytoplasmic domains are found commonly among members of the cytokine receptor superfamily, including i.a. receptors for prolactin and GH (Boutin et al., 1989; Fukunaga et al., 1990; Vigon et al., 1992). Also for these receptors, the physiological relevance for the existence of truncated receptor variants is unknown.

The hypothalamic arcuate nucleus may be a main target of circulating leptin. When monosodium glutamate (MSG) is given to neonatal animals, $80-90 \%$ of the neurons in the adult arcuate nucleus are eliminated, and a syndrome including massive obesity is seen (see Meister, 1991). Neurons in the ventromedial part of the arcuate nucleus, in which receptors for leptin and NPY neurons primarily are present, are absent in MSG animals (see Meister, 1991). A target action of leptin in the ventromedial arcuate nucleus is supported by the present results as well as the presence of ${ }^{125}$ I-leptin binding sites and LR mRNA in this part of the nucleus. It is an open question how circulating leptin reaches 


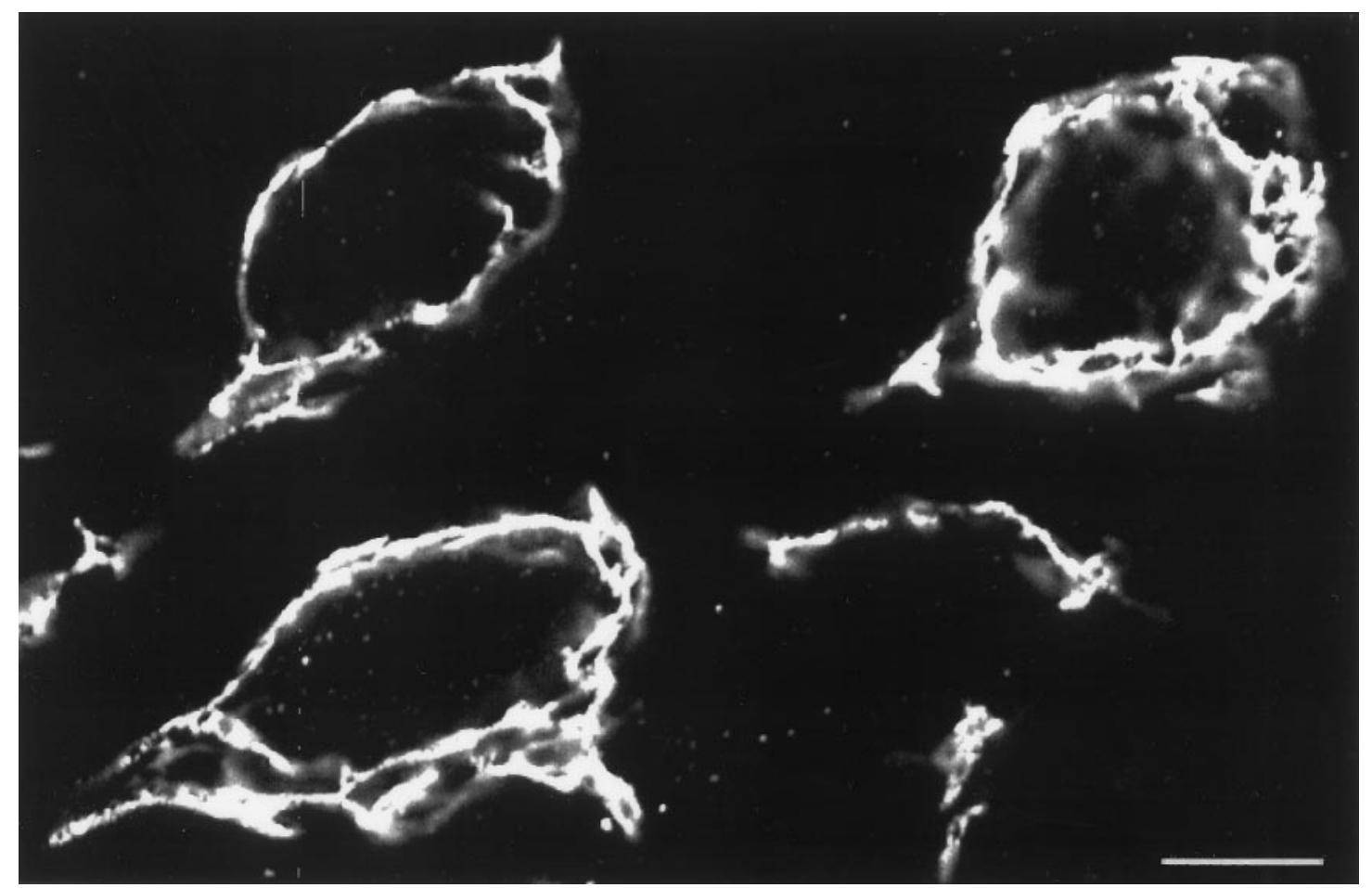

Figure 5. Immunofluorescence image of a section of the supraoptic nucleus obtained via confocal laser scanning microscopy after incubation with antiserum to LR. Note that LR-LI is present in the periphery of individual neurons. Scale bar, $50 \mu \mathrm{m}$.

the arcuate nucleus. When ${ }^{125}$ I-leptin is injected intravenously, the protein is transported across the blood-brain barrier (BBB) at a rate 20 times faster than albumin, and $\sim 75 \%$ of extravascular ${ }^{125}$ I-leptin in brain crosses the BBB completely to reach brain parenchyma (Banks et al., 1995). Autoradiographic data have shown binding of ${ }^{125}$ I-leptin in the arcuate nucleus-median eminence complex, but outside of this region uptake of ${ }^{125} \mathrm{I}$-leptin is diffuse (Banks et al., 1996). Because the median eminence was labeled with ${ }^{125} \mathrm{I}$-leptin, it is likely that leptin reaches the cells in the arcuate nucleus via the median eminence, a structure that belongs to the circumventricular organs, i.e., regions known to lack a BBB. Furthermore, there is evidence that the ventral but not the dorsal part of the arcuate nucleus lacks a BBB (Shaver et al., 1992). It is possible therefore that the leptin secreted exclusively from adipocytes is transported to the brain via the general circulation and acts on LR located in the ventromedial arcuate nucleus devoid of BBB. Leptin also may traverse through the median eminence via specialized ependymal cells, the so-called tanycytes, into the third ventricle and thereafter reach other brain regions as well as the choroid plexus. Although LR is present in many other hypothalamic nuclei, it is possible that accessability to LR in the arcuate nucleus plays a crucial role. It has been speculated that reduced entry of leptin into the brain may be one of the mechanisms underlying reduced sensitivity to leptin in obese individuals (see Campfield et al., 1995).

The double-labeling experiments showed co-localization of LR- and NPY-LI in the same arcuate neurons, in agreement with results showing co-localization LR and NPY at the mRNA level in the arcuate nucleus (Håkansson et al., 1996; Mercer et al., 1996b). The NPY neurons in the arcuate nucleus have been demonstrated to project to the PVN (Bai et al., 1985). Because NPY is a positive regulator of feeding behavior, particularly of carbohydrates (Clark et al., 1984; Stanley et al., 1986), it has been suggested that NPY is an important mediator of the action of leptin in the CNS (see Rohner-Jeanrenaud et al., 1996). In support of this view are results showing that recombinant leptin inhibits hypothalamic NPY gene expression (Stephens et al., 1995; Schwartz et al., 1996a,b) and NPY secretion (Stephens et al., 1995). Leptin also inhibits expected feeding after NPY administration, suggesting that leptin determines the sensitivity of the feeding response to exogenous NPY (Smith et al., 1996). Further evidence for a connection between leptin and NPY neurons is that LR and NPY mRNA levels in the arcuate nucleus are higher in $o b / o b$ mice compared with lean littermates, and both LR and NPY mRNA are downregulated in the arcuate nucleus after leptin administration (Stephens et al., 1995; Schwartz et al., 1996a,b; Mercer et al., 1997). On the other hand, NPY-deficient mice have normal weight and respond to peripheral administration of leptin (Erickson et al., 1996a). These latter observations would indicate that, in addition to NPY, other mediators may play important roles in mediating leptin action. However, generation of $o b / o b$ mice (leptin-deficient) that also are deficient for NPY show that NPY is a central effector of leptin deficiency (Erickson et al., 1996b). In the absence of NPY, ob/ob mice are less obese because of reduced food intake and increased energy expenditure and are affected less severely by diabetes, sterility, and somatotropic effects (Erickson et al., 1996b).

The presence of LR in proopiomelanocortin (POMC) neurons of the arcuate nucleus is interesting. POMC-derived peptides such as $\beta$-endorphin (see Sanger, 1981) and melanocytestimulating hormone (melanocortin) (see below) have been shown to be effectors of feeding and therefore may be important mediators of leptin on the CNS. Similar to the NPY neurons, the large POMC-containing neurons of the arcuate nucleus show rich projections to the PVN (see Everitt et al., 1986). That NPY and POMC neurons project to the PVN suggest that the arcuate 


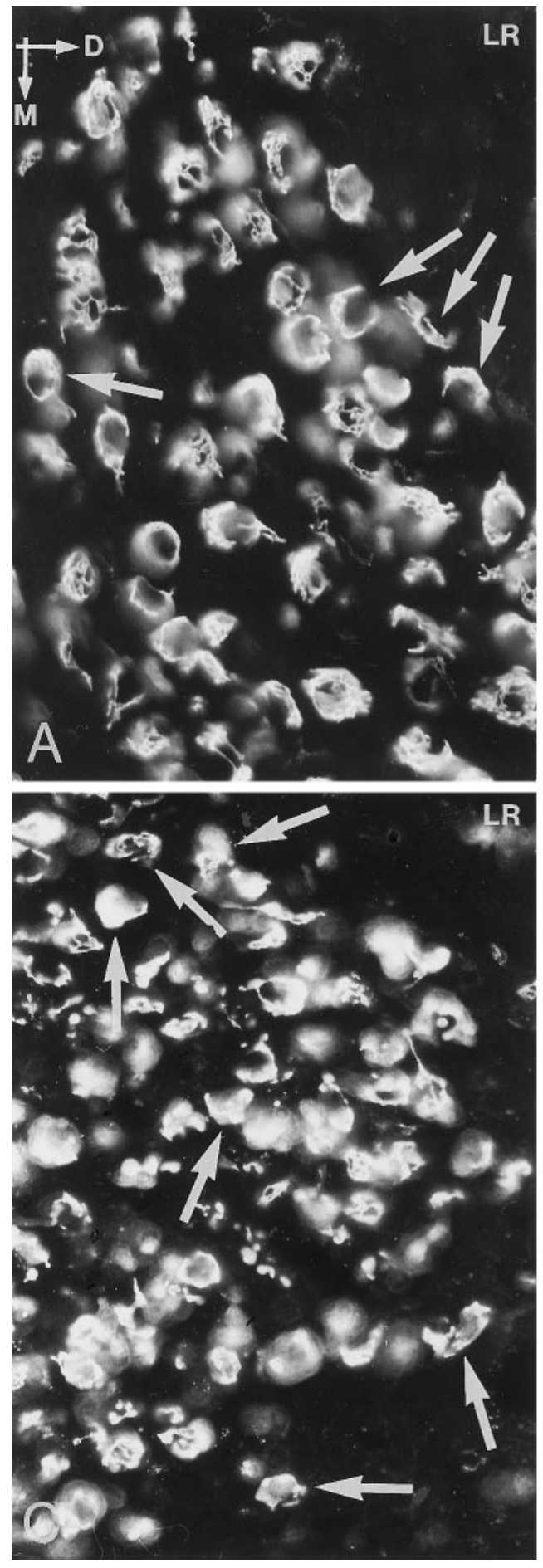

Figure 6. Immunofluorescence photomicrographs of sections of the supraoptic nucleus $(A, B)$ and the magnocellular part of the paraventricular nucleus $(C, D)$ after direct double labeling combining antiserum to $\operatorname{LR}(A, C)$ with antiserum to oxytocin $(O T)$ and vasopressin $(V P)$. Comparison of $A$ with $B$ and $C$ with $D$ shows that LR-LI is present in both VPand OT-containing neurons (arrows). D, Dorsal direction; $M$, medial direction. Scale bar, $50 \mu \mathrm{m}$. neurons, which may be located outside of the BBB (see above), both operate via the PVN to reduce food intake. The large POMC-containing neurons in the ventrolateral arcuate nucleus contain NPY-Y1 receptor-LI (Zhang et al., 1994a), which suggests an interaction between NPY and POMC neurons within the arcuate nucleus. NPY stimulates hypothalamic $\beta$-endorphin release (Kalra et al., 1995).

LR-LI was also demonstrated in some parvocellular neurons of the dorsomedial and ventrolateral arcuate nucleus. These neurons are known to project to the external layer of the median eminence and to influence the secretion of anterior pituitary hormones. Such neurons have been shown to co-contain a large number of neurotransmitters and peptides, including GHRH, GAL, neurotensin, tyrosine hydroxylase, GABA, and acetylcholine (see Meister, 1993). Both GAL (Tempel et al., 1985) and GHRH (Vaccarino et al., 1985) are peptides that affect feeding behavior.

An interaction of leptin with the hypothalamo-pituitary-adrenal axis is supported by our demonstration of LR-LI in CRHcontaining neurons in the parvocellular part of the PVN. Leptin administered into the third ventricle of lean rats caused an increased CRH gene expression in the PVN (Schwartz et al., 1996b). Because CRH inhibits feeding when administered intrac- 


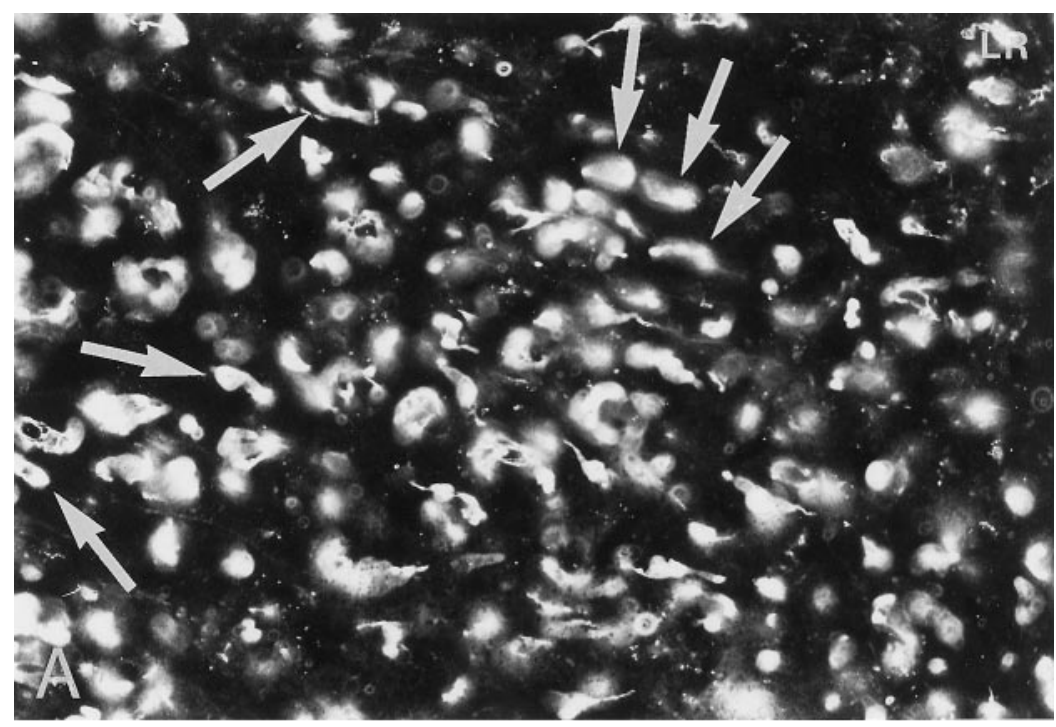

Figure 7. Immunofluorescence photomicrographs of sections of the parvocellular part of the paraventricular nucleus after direct double labeling combining antiserum to LR $(A)$ with antiserum to corticotropin-releasing hormone $(\mathrm{CRH})$ (B). Cells that contain both LR- and CRH-LI are indicated by arrows. Scale bar, $50 \mu \mathrm{m}$.

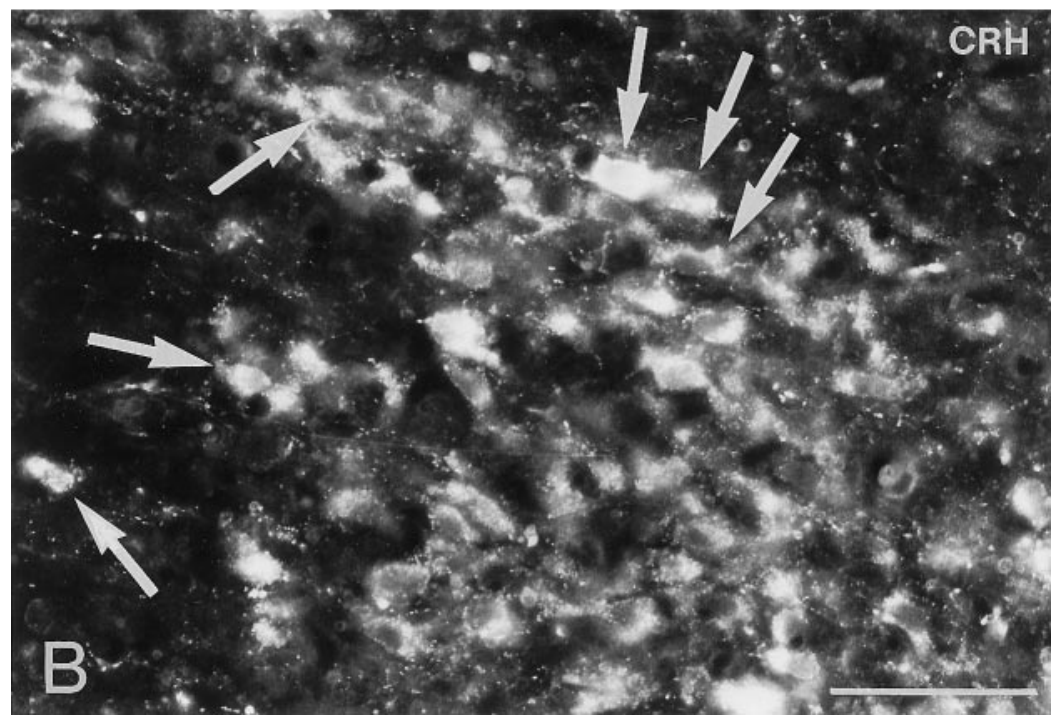

erebroventricularly (Kaiyala et al., 1995; Schwartz et al., 1994), this indicates that the weight-reducing effect of leptin may be mediated in part via an increased CRH expression. The present morphological results give further support for an interaction between leptin and parvocellular CRH neurons of the PVN but suggest also that LR is co-localized with GAL in the parvocellular PVN, because CRH and GAL are present in the same cells in this region (Ceccatelli et al., 1989).

Using differential display PCR, the mRNA encoding the neuropeptide $\mathrm{MCH}$ has been shown to be overexpressed in the hypothalamus of $o b / o b$ mice (Qu et al., 1996). Fasting increased expression of MCH mRNA in both normal and obese animals (Qu et al., 1996). The neurons containing $\mathrm{MCH}$ are located exclusively in the zona incerta and lateral hypothalamus (Skofitsch et al., 1985), regions known to be involved in regulation of ingestive behavior. Injection of $\mathrm{MCH}$ into the lateral ventricle of rats resulted in increased food consumption ( $\mathrm{Qu}$ et al., 1996). Taken together, these findings suggest that $\mathrm{MCH}$ participates in hypothalamic regulation of body weight. Our results show that LR-LI is present in many $\mathrm{MCH}$-containing neurons in the lateral hypothalamus and would suggest that $\mathrm{MCH}$ is also a mediator of the action of leptin to induce reduction of body weight via the CNS.

Apart from being massively obese and having diabetes, $o b / o b$ mice exhibit infertility with male mice having low levels of testosterone and female mice showing delayed ovulation. When fasted mice were treated with leptin, these abnormalities were reversed (Ahima et al., 1996). Administration of leptin to female $o b / o b$ mice restored reproductive function to near normal, and mice became pregnant and carried litters to term successfully (Chehab et al., 1996). Because our results showed few if any neurons having both LR- and LHRH-LI, the effect of leptin on the reproductive system may be related to a direct action on the gonads or an indirect effect on the pituitary rather than the hypothalamus via LHRH neurons. LR mRNA has been detected in the ovary, testis, and pituitary (Zamorano et al., 1996). However, negative results should be treated with caution, and it cannot be excluded that low levels of LR-LI are present in LHRH neurons. Furthermore, a role via other hypothalamic messengers is also possible.

The presence of strong LR-LI in VP- and OT-containing neurons suggests that leptin, apart from being a central regulator of food intake, also may affect neurons that have well known functions in regulation of fluid balance and smooth muscle contractility.

In conclusion, this study shows wide distribution of LR-LI in the brain, in agreement with the earlier studies on LR mRNA. LR-LI is present in neurons that have been shown to be impor- 

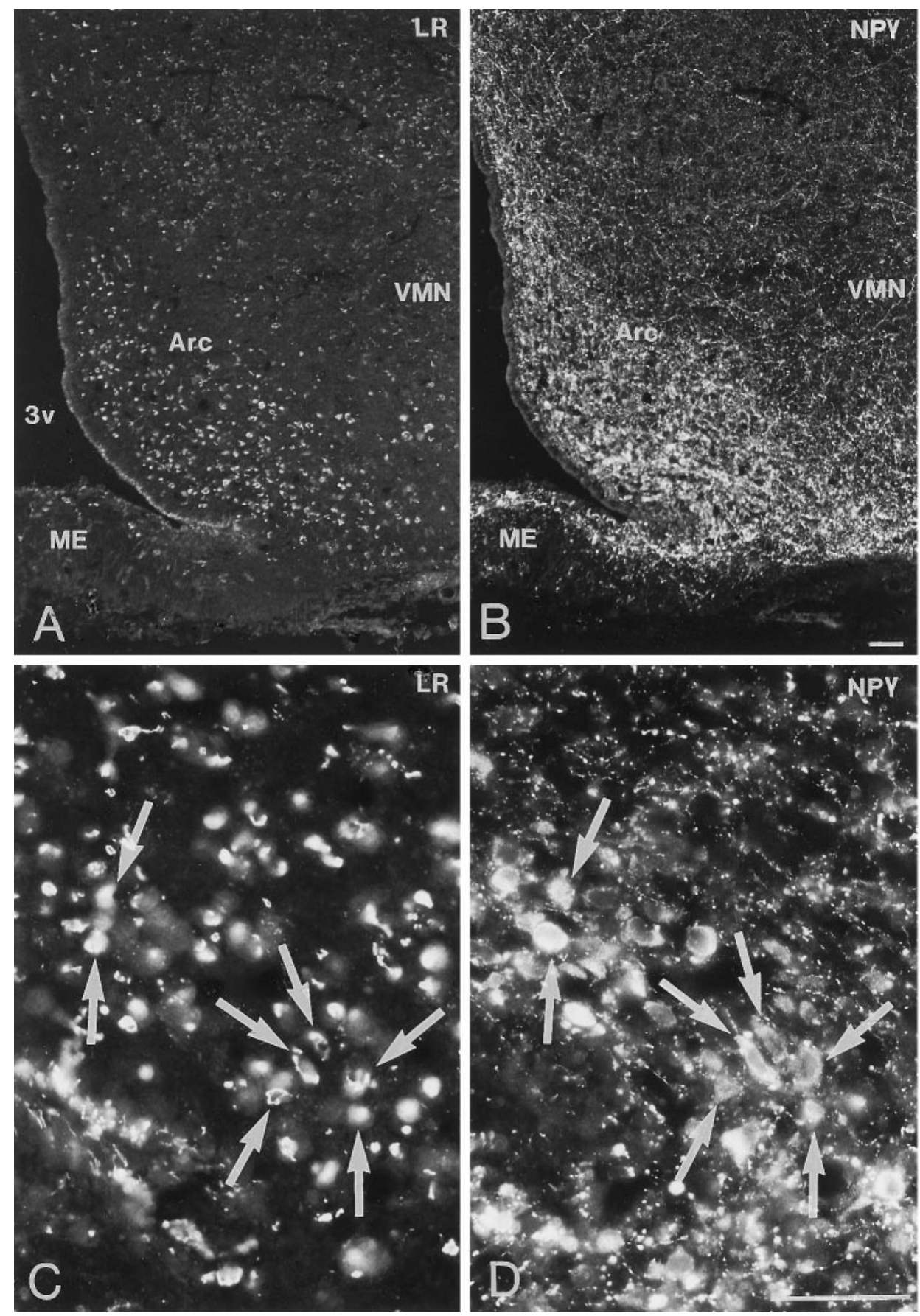

Figure 8. Immunofluorescence photomicrographs of sections of the arcuate nucleus $(A r c)$ after direct double labeling combining antiserum to LR ( $A$, $C)$ with antiserum to neuropeptide Y $(N P Y)(B, D)$. LR- and NPY-positive neurons are located mainly in the ventromedial part of the Arc. Double labeling shows that LR-LI is present in many NPY-containing neurons (arrows). ME, Median eminence; $V M N$, ventromedial nucleus; $3 v$, third ventricle. Scale bars, $50 \mu \mathrm{m}$. 

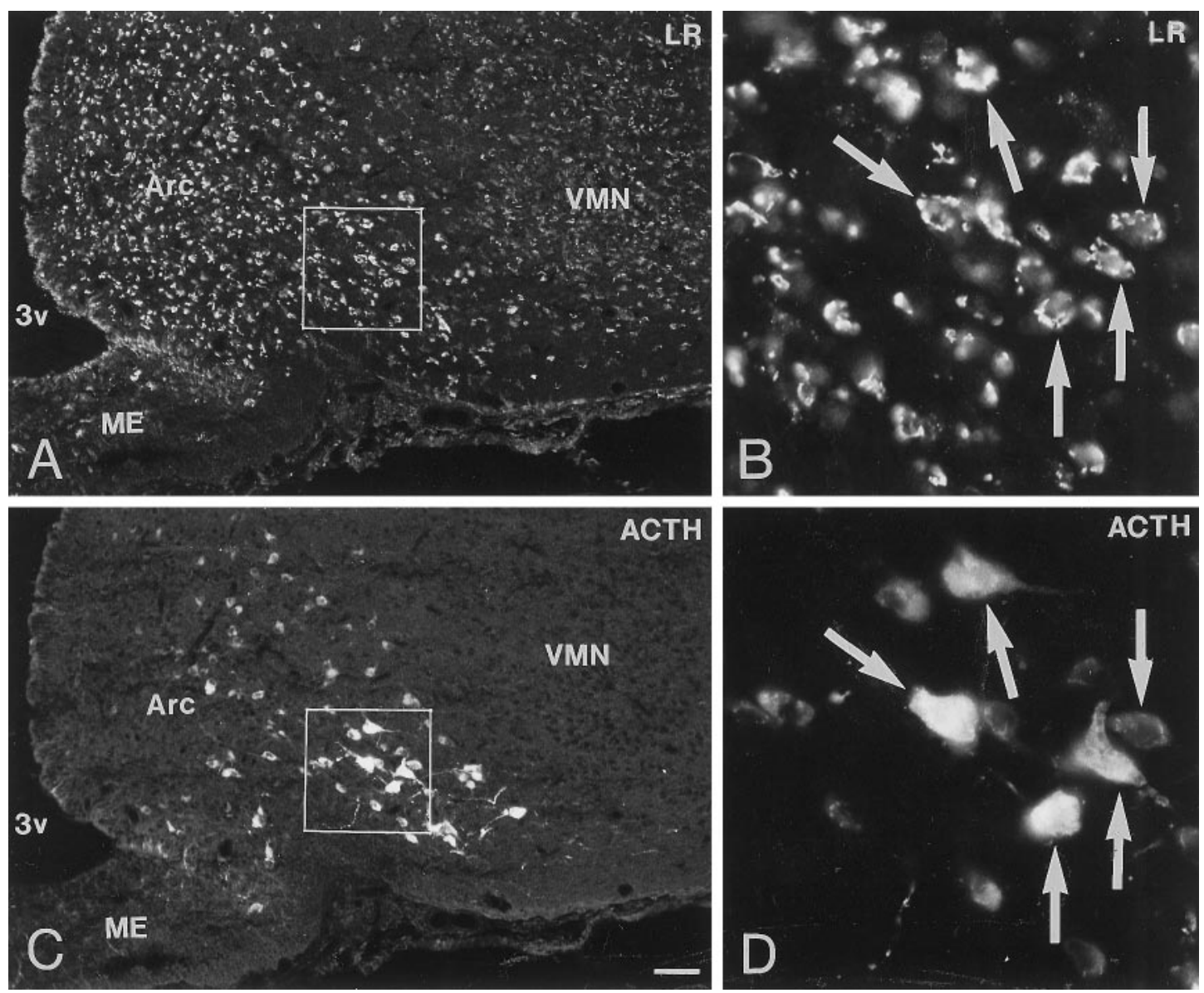

Figure 9. Immunofluorescence photomicrographs of sections of the arcuate nucleus $(A r c)$ after direct double labeling combining antiserum to LR ( $A$, $C)$ with antiserum to adrenocorticotropic hormone $(A C T H)(B, D)$. Large ACTH-positive POMC-containing neurons are distributed in the ventrolateral part of the Arc. Double labeling shows co-localization of LR- and ACTH-LI in many neurons (arrows). Scale bar, $50 \mu \mathrm{m}$. 


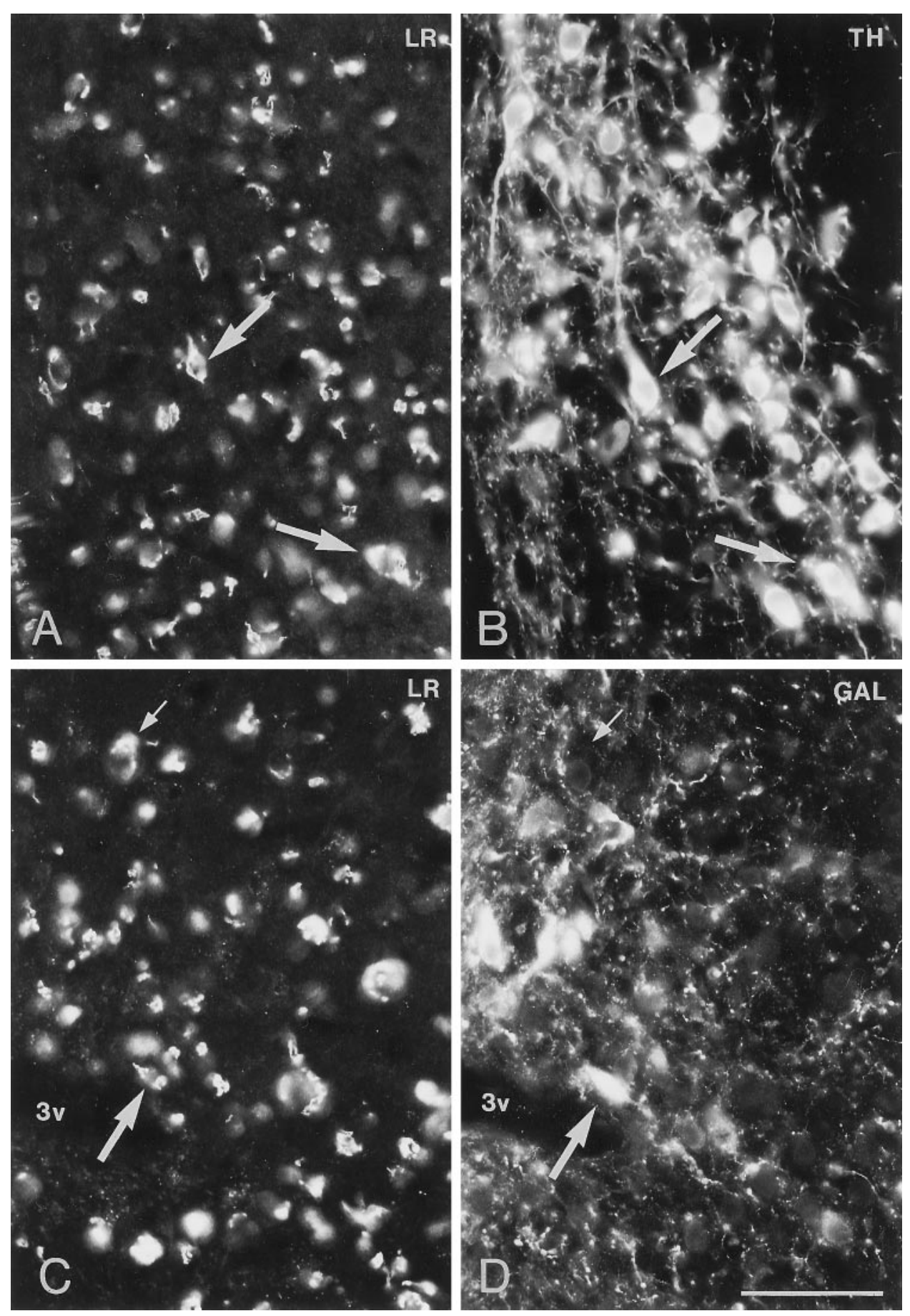

Figure 10. Immunofluorescence photomicrographs of sections of the arcuate nucleus $(A r c)$ after direct double labeling combining antiserum to LR ( $A$, $C)$ with antiserum to tyrosine hydroxylase $(T H)(B)$ or galanin $(G A L)(D)$. Scale bars, $50 \mu \mathrm{m}$. 

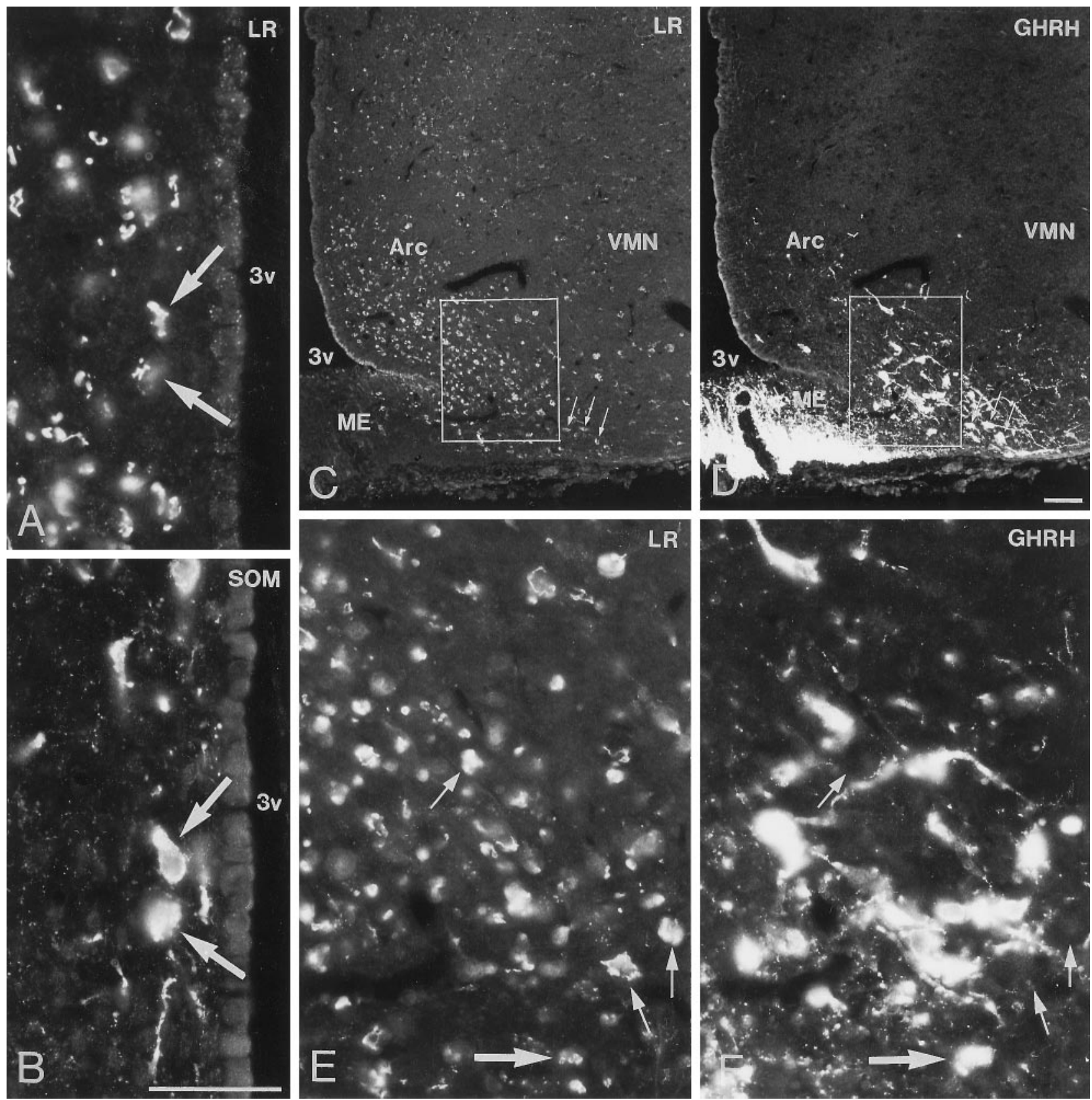

Figure 11. Immunofluorescence photomicrographs of sections of the periventricular nucleus $(A, B)$ and arcuate nucleus $(A r c)(C-F)$ after direct double labeling combining antiserum to $\operatorname{LR}(A, C, E)$ with antiserum to somatostatin $(S O M)(B)$ or growth hormone-releasing hormone $(G H R H)(D, F)$. Some LR-IR cells of the periventricular nucleus are SOM-positive (arrows). LR-IR neurons are distributed mainly in the ventromedial part of the Arc, whereas GHRH-containing neurons are mainly present in the ventrolateral part $(C, D)$. Some neurons in the far ventrolateral part contain both LR- and GHRH-LI (small arrows in $C, D$ ). There are many LR-IR neurons that are GHRH-negative (small arrows in $E, F$ ) and many GHRH-positive neurons that are LR-negative. Few neurons contain both LR- and GHRH-LI (large arrow in $E, F$ ). $M E$, Medan eminence; $3 v$, third ventricle. Scale bars, $50 \mu$ m. 

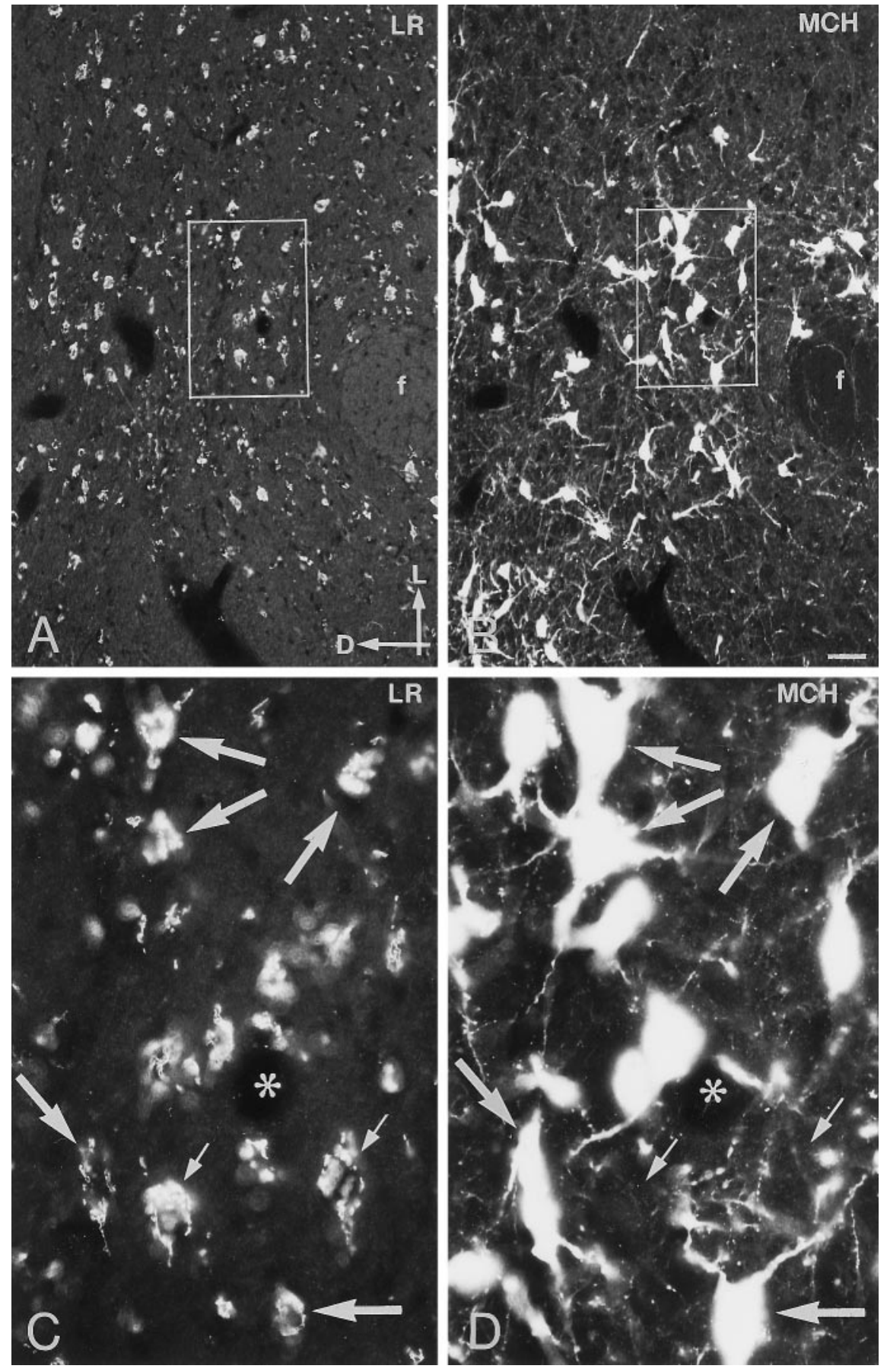

Figure 12. Immunofluorescence photomicrographs of sections of the lateral hypothalamus after direct double labeling combining antiserum to $\operatorname{LR}(A, C)$ with antiserum to melanin-concentrating hormone $(M C H)(B, D)$. Many LR- and MCH-positive neurons are distributed in the lateral hypothalamus. Direct double labeling shows that there are several cells that contain both LR- and MCH-LI (large arrows). Neurons that have LR-LI but apparently lack MCH-LI are also present (small arrows). Asterisks indicate vessels. $D$, dorsal; $f$, fornix; $L$, lateral. Scale bar, $50 \mu \mathrm{m}$. tant for the control of ingestive behavior. The wide distribution of LR-LI in many different hypothalamic nuclei suggests that, in addition, leptin may participate in the control of other neuroendocrine systems.

\section{REFERENCES}

Ahima RS, Prabakaran D, Mantzoros C, Qu D, Lowell B, Maratos-Flier E, Flier JS (1996) Role of leptin in the neuroendocrine response to fasting. Nature 382:250-252.

Bai FL, Yamano M, Shiotani Y, Emson P, Smith AD, Powell JF, Tohyama M (1985) An arcuato-paraventricular and dorsomedial hypothalamic neuropeptide Y-containing system which lacks noradrenaline in the rat. Brain Res 331:172-175.

Banks WA, Kastin A J, Huang W, Jaspan JB, Maness LM (1996) Leptin enters the brain by a saturable system independent of insulin. Peptides 17:305-311.

Baumann H, Morella KK, White DW, Dembski M, Bailon PS, Kim HK, Lai CF, Tartaglia LA (1996) The full-length leptin receptor has signaling capabilities of interleukin 6-type cytokine receptors. Proc Natl Acad Sci USA 93:8374-8378.

Boutin JM, Edery M, Shirota M, Jolicoeur C, Lesuer L, Ali S, Gould D, Djiane J, Kelly PA (1989) Identification of a cDNA encoding a long form form of prolactin receptor in human hepatoma and breast cancer cells. Mol Endocrinol 3:1455-1461.

Campfield LA, Smith FJ, Guisez Y, Devos R, Burn P (1995) Recombinant mouse $\mathrm{OB}$ protein: evidence for a peripheral signal linking adiposity and central neural networks. Science 269:546-549.

Ceccatelli S, Eriksson M, Hökfelt T (1989) Distribution and coexistence of corticotropin-releasing factor-, neurotensin-, enkephalin-, 
cholecystokinin-, galanin- and vasoactive intestinal polypeptide/peptide histidine isoleucine-like peptides in the parvocellular part of the paraventricular nucleus. Neuroendocrinology 49:309-323.

Chehab F, Lim M, Lu R (1996) Correction of the sterility effect in homozygous obese female by treatment with human recombinant leptin. Nat Genet 12:318-320.

Chen H, Charlat O, Tartaglia LA, Woolf EA, Ellis SJ, Lakey ND, Culpepper J, Moore KJ, Breitbart RE, Duyk GM, Tepper RI, Morgenstern JP (1996) Evidence that the diabetes gene encodes the leptin receptor: identification of a mutation in the leptin receptor gene in $d b / d b$ mice. Cell 84:491-495.

Clark JT, Kalra PS, Crowley WR, Kalra SP (1984) Neuropeptide Y and human pancreatic polypeptide stimulate feeding behavior in rats. Endocrinology 115:427-429.

Coleman DL (1973) Effects of parabiosis of obese with diabetes and normal mice. Diabetologia 9:294-298.

Erickson JC, Clegg KE, Palmiter RD (1996a) Sensitivity to leptin and susceptibility to seizures of mice lacking neuropeptide Y. Nature 381:415-418.

Erickson JC, Hollopeter G, Palmiter RD (1996b) Attenuation of the obesity syndrome of $o b / o b$ mice by the loss of neuropeptide Y. Science 274:1704-1707.

Everitt BJ, Meister B, Hökfelt T, Melander T, Terenius L, Rökaeus Å, Theodorsson-Norheim E, Dockray G, Edwardson J, Cuello C, Elde R, Goldstein M, Hemmings H, Ouimet C, Walaas I, Greengard P, Vale W, Weber E, Wu JY, Chang KJ (1986) The hypothalamic arcuate nucleus-median eminence complex: immunohistochemistry of transmitters, peptides and DARPP-32 with special reference to coexistence in dopamine neurons. Brain Res Rev. 11:97-155.

Fei H, Okano HJ, Li C, Lee G-H, Zhao C, Darnell R, Friedman JM (1997) Anatomic localization of alternatively spliced leptin receptors (Ob-R) in mouse brain and other tissues. Proc Natl Acad Sci USA 94:7001-7005.

Fukunaga R, Seto Y, Mizushima S, Nagata S (1990) Three different mRNAs encoding human granulocyte colony stimulating factor receptor. Proc Natl Acad Sci USA 87:8702-88706.

Ghilardi N, Skoda RC (1997) The leptin receptor activates janus kinase 2 and signals for proliferation in a factor dependent cell line. Mol Endocrinol 11:393-399.

Ghilardi N, Ziegler S, Wiestner A, Stoffel R, Heim MH, Skoda RC (1996) Defective STAT signaling by the leptin receptor in diabetic mice. Proc Natl Acad Sci USA 93:6231-6235.

Håkansson M-L, Hulting A-L, Meister B (1996) Expression of leptin receptor mRNA in the hypothalamic arcuate nucleus-relationshhip with NPY neurones. NeuroReport 7:3087-3092.

Halaas JL, Gajiwala KS, Maffei M, Cohen SL, Chalt BT, Rabinowitz D, Lallone RL, Vurley SK, Friedman JM (1995) Weightreducing effects of the plasma protein encoded by the obese gene. Science 269:543-546.

Huang XF, Koutcherov I, Lin S, Wang HO, Storlien L (1996) Localization of leptin receptor mRNA expression in mouse brain. NeuroReport $7: 2635-2638$.

Hummel KP, Dickie MM, Coleman DL (1966) Diabetes, a new mutation in the mouse. Science 153:1127-1128.

Ihle JN (1996) STATs: signal transducers and activators of transcription. Cell 84:331-334.

Kaiyala KJ, Woods SC, Schwarts MW (1995) New model for the regulation of energy balance and adiposity by the central nervous system. Am J Clin Nutr 62:1123s-1134s.

Kalra PS, Norlin M, Kalra SP (1995) Neuropeptide Y stimulates betaendorphin release in the basal hypothalamus: role of gonadal steroids. Brain Res 705:353-356.

Lee G-H, Proenca R, Montez JM, Carroll KM, Darvishzadeh JG, Lee JI, Friedman JM (1996) Abnormal splicing of the leptin receptor in diabetic mice. Nature 379:632-635.

Meister B (1991) Monosodium glutamate (MSG) lesions. In: Methods in neurosciences, Vol 7, Transplantation, lesions, and surgical techniques, Chap 6 (Conn PM, ed), pp 70-89. Orlando: Academic.

Meister B (1993) Gene expression and chemical diversity in hypothalamic neurosecretory neurons. Mol Neurobiol 7:87-110.

Mercer JG, Hoggard N, Williams LM, Lawrence CB, Hannah LT, Trayhurn P (1996a) Localization of leptin receptor mRNA and the long form splice variant $(\mathrm{Ob}-\mathrm{Rb})$ in mouse hypothalamus and adjacent brain regions by in situ hybridization. FEBS Lett 387:113-116.

Mercer JG, Hoggard N, Williams LM, Lawrence CB, Hannah LT, Mor- gan PJ, Trayhurn P (1996b) Coexpression of leptin receptor and preproneuropeptide Y mRNA in arcuate nucleus of mouse hypothalamus. J Neuroendocrinol 8:733-735.

Mercer JG, Moar KM, Rayner DV, Trayhurn P, Hoggard N (1997) Regulation of leptin receptor and NPY gene expression in hypothalamus of leptin-treated obese $(o b / o b)$ and cold exposed mice. FEBS Lett 402:185-188.

Pelleymounter MA, Cullen MJ, Baker MB, Hecht R, Winters D, Boone T, Collins F (1995) Effects of the obese gene product on body weight regulation in $o b / o b$ mice. Science 269:540-543.

Qu D, Ludwig DS, Gammeltoft S, Piper M, Pelleymounter MA, Cullen MJ, Mathes WF, Przypek J, Kanarek R, Maratos-Flier E (1996) A role for melanin-concentrating hormone in the central regulation of feeding behaviour. Nature 380:243-247.

Rohner-Jeanrenaud F, Cusin I, Sainsbury A, Zakrewska KE, Jeanrenaud B (1996) The loop between neuropeptide $\mathrm{Y}$ and leptin in normal and obese rodents. Horm Metab Res 28:642-648.

Sanger DJ (1981) Endorphinergic mechanisms in the control of food and water intake. Appetite 2:193-198.

Schwartz MJ, Fielewicz DP, Baskin DG, Woods SC, Porte Jr D (1994) Insulin and the central regulation of energy balance: update 1994. Endocr Rev 2:109-113.

Schwartz MW, Seeley RJ, Campfield LA, Burn P, Baskin DG (1996a) Identification of targets of leptin action in rat hypothalamus. Clin Invest 98:1101-1106.

Schwartz MW, Baskin DG, Bukowski TR, Kuijper JL, Foster D, Lasser G, Prunkard DE, Porte Jr D, Woods SC, Seely RJ, Weigle DS (1996b) Specificity of leptin action on elevated blood glucose and hypothalamic neuropeptide Y gene expression in $o b / o b$ mice. Diabetes 45:531-535.

Shaver SW, Pang JJ, Wainman DS, Wall KM, Gross PM (1992) Morphology and function of capillary network in subregions of the rat tuber cinereum. Cell Tissue Res 267:437-448.

Skofitsch G, Jacobowitz DM, Zamir N (1985) Immunohistochemical localization of a melanin concentrating hormone-like peptide in the rat brain. Brain Res Bull 15:635-649.

Smith FJ, Campfield LA, Moschera JA, Bailon P (1996) Feeding inhibition by neuropeptide Y. Nature 381:415-418.

Stanley BG, Kyrkouli SE, Lampert S, Leibowitz SF (1986) Neuropeptide Y chronically injected into the hypothalamus: a powerful neurochemical inducer of hyperphagia and obesity. Peptides 7:1189-1192.

Stephens TW, Basinski M, Bristow PK, Bue-Vallesky JM, Burgett SG, Craft L, Hale J, Hoffmann J, Hsiung HM, Kriauciunas A, MacKellar W, Rosteck Jr PR, Schoner B, Smith D, Tinsley FC, Zhang X-Y, Heiman M (1995) The role of neuropeptide $Y$ in the antiobesity action of the obese gene product. Nature 377:530-532.

Tartaglia LA, Dembski M, Weng X, Deng N, Culpepper J, Devos R, Richards GJ, Campfield LA, Clark FT, Deeds J, Muir C, Sanker S, Moriarty A, Moore KJ, Smutko JS, Mays GG, Woolf EA, Monroe CA, Tepper RI (1995) Identification and expression cloning of a leptin receptor, OB-R. Cell 83:1263-1271.

Tempel DL, Leibowitz KJ, Leibowitz SF (1985) Effects of PVN galanin on macronutrient selection. Peptides 9:309-314.

Vaccarino FJ, Bloom FE, Rivier J, Vale W, Koob GF (1985) Stimulation of food intake in rats by centrally administered hypothalamic growth hormone releasing factor. Nature 314:167-168

Vigon I, Mornon JP, Cocault L, Mitjarila MT, Tambourin P (1992) Molecular cloning and characterization of MPL, the human homologue of the v-mpl oncogene: identification of a member of the hematopoietic growth factor superfamily. Proc Natl Acad Sci USA 89:5640-5644.

Zamorano PL, Mahesh VB, DeSevilla LM, Chorich LP, Bhat GK, Brann DW (1996) Expression and localization of the leptin receptor in endocrine and neuroendocrine tissues of the rat. Neuroendocrinology 65:223-228

Zhang F, Basinski MB, Beals JM, Briggs SL, Churgay LM, Clawson DK, DiMarchi RD, Furman TC, Hale JE, Hsiung HM, Schoner BE, Smith DP, Zhang XY, Wery J-P, Schevitz RW (1997) Crystal structure of the obese protein leptin-E100. Nature 387:206-209.

Zhang X, Bao L, Xu ZQ, Kopp J, Arvidsson U, Elde R, Hökfelt T (1994a) Localization of neuropeptide Y Y1 receptors in the rat nervous system with special reference to somatic receptors on small dorsal root ganglion neurons. Proc Natl Acad Sci USA 91:11738-11742.

Zhang Y, Proenca R, Maffei M, Barone M, Leopold L, Friedman JM (1994b) Positional cloning of the mouse obese gene and its human homologue. Nature 372:425-432. 